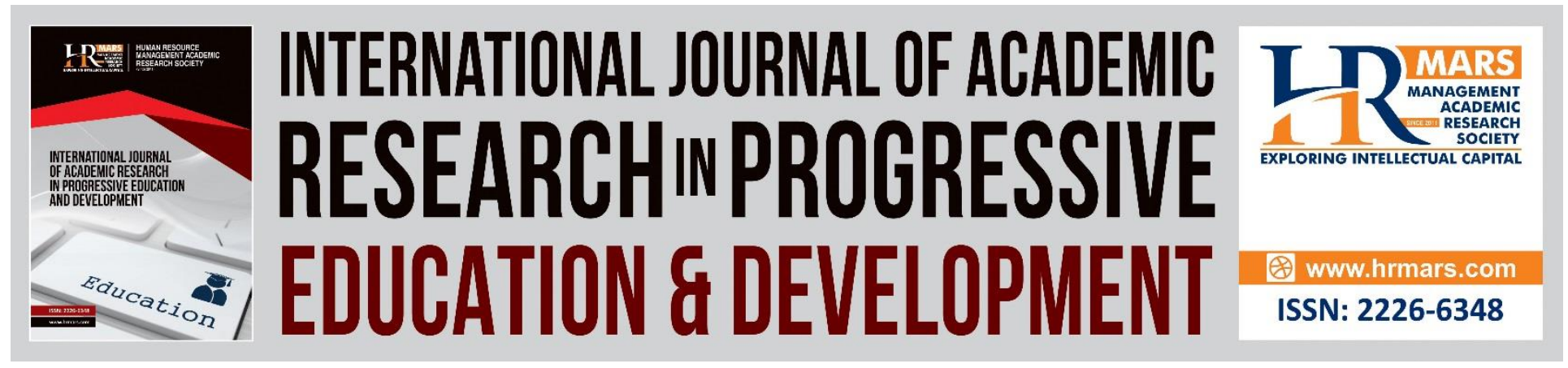

\title{
Teachers' Knowledge of Higher Order Thinking and Questioning Skills: A Case Study at a Primary School in Terengganu, Malaysia
}

\section{Wan Mazwati Wan Yusoff, Shamilati Che Seman}

To Link this Article: http://dx.doi.org/10.6007/IJARPED/v7-i2/4120

DOI: $10.6007 /$ IJARPED/v7-i2/4120

Received: 11 April 2018, Revised: 11 May 2018, Accepted: 24 May 2018

Published Online: 28 May 2018

In-Text Citation: (Yusoff \& Seman, 2018)

To Cite this Article: Yusoff, W. M. W., \& Seman, S. C. (2018). Teachers' Knowledge of Higher Order Thinking and Questioning Skills: A Case Study at a Primary School in Terengganu, Malaysia. International Journal of Academic Research in Progressive Education and Development, 7(2), 45-63.

\section{Copyright: (c) 2018 The Author(s)}

Published by Human Resource Management Academic Research Society (www.hrmars.com)

This article is published under the Creative Commons Attribution (CC BY 4.0) license. Anyone may reproduce, distribute, translate and create derivative works of this article (for both commercial and non-commercial purposes), subject to full attribution to the original publication and authors. The full terms of this license may be seen at: http://creativecommons.org/licences/by/4.0/legalcode

\section{Vol. 7, No. 2, April 2018, Pg. 45 - 63}

Full Terms \& Conditions of access and use can be found at http://hrmars.com/index.php/pages/detail/publication-ethics 


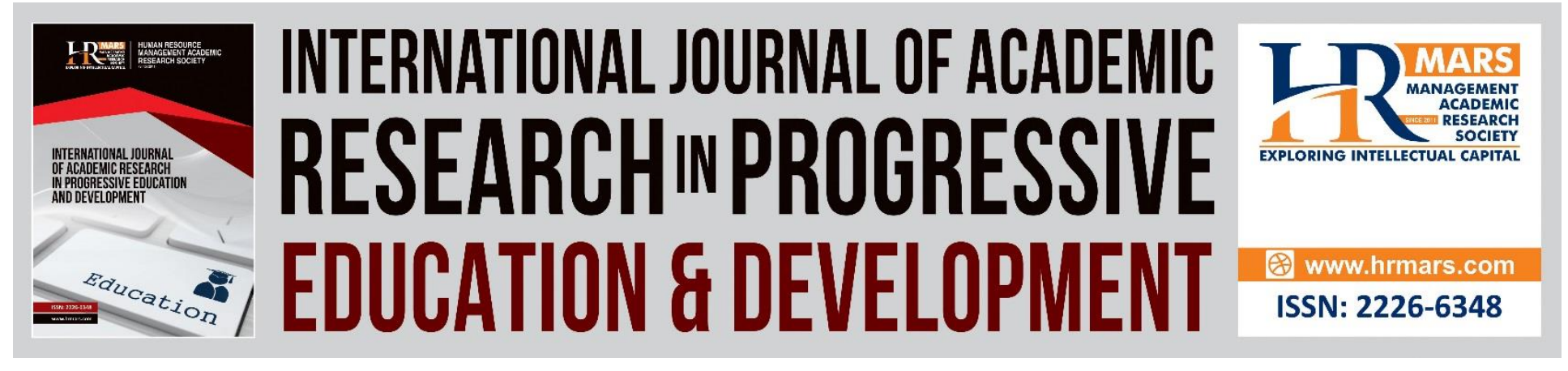

\title{
Teachers' Knowledge of Higher Order Thinking and Questioning Skills: A Case Study at a Primary School in Terengganu, Malaysia
}

\author{
Wan Mazwati Wan Yusoff \\ Department of Fundamental and Inter-Disciplinary Studies, Kulliyyah of Islamic Revealed \\ Knowledge and Human Sciences, International Islamic University Malaysia, 53100 Kuala \\ Lumpur, Malaysia. Email: wanmazwati@iium.edu.my
}

Shamilati Che Seman

Sekolah Kebangsaan Gong Badak, Kuala Nerus, 21300 Terengganu, Malaysia.

\begin{abstract}
The purpose of this research was to explore primary school teachers' knowledge of higher order thinking (HOTS) and questioning skills. This was done because little is known about the level of teachers' knowledge and skills in HOTS; and their knowledge and skills in questioning to stimulate HOTS. To this end this paper employed exploratory case study to gain an in-depth understanding of this phenomenon in the actual setting so that the actual behaviour can be examined with minimum interference that may obstruct the reality. Nine primary school teachers were selected to be interviewed and observed. Semi-structured interview questions were used to collect data on teachers understanding of the concept of thinking and higher order thinking skills; and Likerttype checklist was used to gather data on the frequencies and types of questions teachers usually asked to promote thinking. Observations were conducted to validate the teachers' responses regarding the frequencies and types of questions asked during teaching and learning sessions. The data gathered through interviews were analysed to determine the emerging themes. The findings revealed that the teachers failed to explain clearly the concept of thinking and thinking processes; and majority of teachers could not give satisfactory explanation of HOTS as critical and creative thinking. However, half of the teachers could list the subskills of HOTS according to Bloom's Taxonomy. Data on teachers' questioning skills revealed that they were familiar with questioning based on Bloom's Taxonomy, however only half of the teachers practised asking HOTS questions based on Bloom's Taxonomy.
\end{abstract}


INTERNATIONAL JOURNAL OF ACADEMIC RESEARCH IN PROGRESSIVE EDUCATION AND

DEVELOPMENT

Vol. 7, No. 2, April 2018, E-ISSN: 2226-6348 @ 2018 HRMARS

Keywords: Higher Order Thinking Skills, Teaching For Hots, Critical Thinking, Creative Thinking, Questioning Skills

\section{Introduction}

The Malaysian Ministry of Education (MOE, 2013) has published a very disheartening result that $60 \%$ of 15 -year-old Malaysian students who had completed lower secondary school failed to achieve minimum proficiency level in thinking skills of knowing, applying, reasoning and in transferring knowledge and skilled learned in classrooms for application in the real-world. MOE further reported that compared to 15-year-old students from Singapore, Hong Kong, South Korea and Shanghai, Malaysia's 15-year-olds were three or more years behind in schooling. Taking into account this discouraging result, MOE has emphasized achievement in thinking skills as one of the aims of strategic planning stated in the Malaysia Education Blueprint 2013-2025. The Blueprint states: "Every child will master a range of important cognitive skills, including critical thinking, reasoning, creative thinking, and innovation" (MOE, 2013: E-7).

To realize the noble aim of producing students who are skilful in higher order thinking, MOE has planned and implemented various reformation in curriculum and innovation in teaching and learning. However, Mohd Azhar, Mohd Koharuddin and Muhamed Fauzi (2006) and Zulkarami (2011) claimed that efforts done by the Ministry of Education were far from reaching the targets. Furthermore, they reported that they did not discover any definite indicator to prove that the culture of HOTS and innovation existed even at a minimal level. Even though the Ministry has produced detailed documents of curriculum and syllabus with state of the art teaching and learning methods and activities, but the most important factor influencing students' achievement in HOTS is the quality of teachers. Teacher makes or breaks the curriculum.

Ministry of Education has made substantial investment in training teachers to teach for HOTS; and it is compulsory for every teacher to know and understand HOTS correctly and clearly (MOE, 2103). However, studies revealed that teachers had only basic knowledge on Bloom's taxonomy of cognitive processes; and they did not understand the functions and the differences between stages of lower order thinking skills and higher order thinking skills. Furthermore, teachers lack knowledge and understanding in methods of teaching for thinking (Abdul Halim \& Siti Muhibah, 2015). The same research also found that teachers were unsuccessful in choosing the appropriate techniques, methods and approaches of teaching for HOTS effectively. What is more, majority of teachers did not know how to teach for HOTS and some teachers were reluctant to do so (Najeemah, 2007; Yee, Razali, Mimi, Widad, \& Tee, 2013); and majority of them had low self-efficacy in teaching for HOTS (Rosnani \& Suhailah, 2003). Another study discovered that teachers' understanding of thinking processes was negligible; and their skills in HOTS were low, but they displayed high interest in HOTS and teaching for HOTS (Rosma, Ong, Shakinaz, \& Wong, 2012).

Even though many teachers lacked knowledge and skills in HOTS, but they had positive perceptions about HOTS and they were confident that teaching for HOTS could enhance students' cognitive abilities (Siti Marlina, 2013). It is shocking, however, to discover that there were still teachers who were not trained in teaching for HOTS yet (Abdul Halim et al., 2015) even though 
DEVELOPMENT

Vol. 7, No. 2, April 2018, E-ISSN: 2226-6348 @ 2018 HRMARS

MOE had instructed teachers to explicitly teach for HOTS since 1989 (MOE, 2013). Recent studies conducted by Nooriza and Effandi (2015) also discovered that teachers had only minimal understanding on the concept of HOTS and they were not well prepared to teach for HOTS. Another study corroborated the findings of Nooriza and Effandi. Mohd Nazri et al. (2017) found that teachers had no adequate knowledge on HOTS and how to teach for HOTS. Teachers were not competent in HOTS and in teaching for HOTS.

However, studies conducted by Nor Hamaliza and Zamri (2016) found that teachers were knowledgeable in HOTS and they had mastered the skills of HOTS. The same study also reported that teachers knew how to teach for HOTS and they were skilful in teaching for HOTS. The findings of this study were substantiated by the findings of a study done by Yahya (2016). Both of these studies were done quantitatively where teachers were asked to indicate whether they agreed or disagreed with the statements provided by researchers. Therefore, the findings of both of these studies did not accurately measure teachers' knowledge and skills in HOTS and their knowledge and skills in teaching for HOTS. The examples of items in their questionnaires were "I understood the concept of HOTS"; "I have knowledge on the concept of HOTS"; and "I know how to teach for HOTS". It is obvious that these studies were not measuring teacher knowledge and skills accurately. It is undisputed that to teach effectively, the teachers must be knowledgeable in the content knowledge and also in pedagogical knowledge; and they must be competent in the skills that they aim to transfer to their students and also competent in teaching those skills.

The motivation to conduct this study was the inconsistency of research findings on teachers' knowledge and competency in teaching for HOTS coupled with the insignificant amout of literature available on this issue in Malaysia. Therefore, this study was done to assess teachers' knowledge of HOTS and skills in teaching for HOTS; and to add to the existing literature on indepth description of teachers' knowledge of HOTS and competency in teaching for HOTS. The respondents for qualitative studies conducted by Nooriza and Effandi (2015) and Mohd Nazri et al. (2017) were four and six respectively, hence, we still could not paint a clear picture of this issue in Malaysia. Better illustration about teacher knowledge and skills in HOTS and teacher knowledge and skills in teaching for HOTS is still wanting. Thus, this present study was conducted to explore and find out teachers' knowledge of HOTS and their knowledge and skills in teaching for HOTS, specifically in asking questions that promote the use of HOTS. According to Elder and Paul (2003), higher order thinking can be stimulated by asking appropriate questions. The insight gained from this study is significant to evaluate the whole project of teaching for HOTS since it was made explicitly in 1989. The result from this study may inform the authority to make the necessary actions, adjustments or modifications of the existing plans and strategies. Moreover, more literature on in-depth description of teacher knowledge and skills in HOTS is needed for better and informed judgement in the success and failure of this project in Malaysian education; and for appropriate action to be taken in teacher education.

\section{Higher Order Thinking Skills}

Thinking is a mental process of combining and arranging data and information in the mind in a correct and meaningful sequence in order to understand or to solve problems be it 


\section{INTERNATIONAL JOURNAL OF ACADEMIC RESEARCH IN PROGRESSIVE EDUCATION AND}

DEVELOPMENT

Vol. 7, No. 2, April 2018, E-ISSN: 2226-6348 @ 2018 HRMARS

understanding new concepts and knowledge, to make decision in believing and acting or to come up with effective, ethical and sustainable solutions for real-world problems. According to Imam al-Ghazali (2007), combining existing knowledge in the mind to make logical and defensible conclusion is an intellectual thinking process. Thinking process begins when the mind recalls the data and information stored in memory to be processed in order to understand. Thinking process progresses to make conclusion based on the existing knowledge to attain certainty and to combine the existing knowledge to generate new ideas to solve problems; and excellent thinking is when these thinking processes are done within the moral and ethical boundary to achieve goodness for all mankind.

Human is not born with thinking skills. Skill is an ability attained as a result of practising knowledge learned regularly until a skilful person would be able to do certain task effortlessly. Therefore, thinking skill is an acquired mental ability through the process of learning; and can be improved through practice. Thinking skill used to process data and information in the mind in order to understand and make conclusion on truth and falsehood is called critical thinking. The subskills of critical thinking are analysis, interpretation, evaluation, inference, explanation, and self-regulation skills. Analysis is to break down texts, statements, objects, videos or other media, or any kind of expressions expressed verbally or visually (written and pictures) to find proposed or actual relationships among them. Interpretation is "to comprehend and express meaning or significance of a wide variety of experiences, situations, data, events, judgments, conventions, beliefs, rules, procedures and criteria" (Facione, 2006: 4). Evaluation is assessing the reliability and strength of evidences of claims and statements; and ensuring that assessment is done based on standards or criteria which can stand critical examination. The subskills of inference include making hypothesis; making conclusion based on evidences; and coming up with logical consequences from data, claims, concepts, beliefs, judgements, and etc. Facione (2006: 6) reported the experts defined explanation as "stating and identifying reasoning in terms of the evidential, conceptual, methodological, criteriological, and contextual considerations upon which one's results were based; and to present one's reasoning in the form of cogent argument". The last core critical thinking skill is self-regulation which means self-awareness of one's own thinking abilities, processes and evaluation of one's own reasons for making conclusions for the purpose of confirming or correcting one's own reasoning or belief. In other words, self-regulation is using reflective and metacognitive thinking to validate or correct one's own reasoning and belief. 
Table 1: Core critical thinking skills and sub-skills

\begin{tabular}{ll}
\hline Core Skill & Sub-Skills \\
\hline Analysis & $\begin{array}{l}\text { Examining ideas; detecting arguments; pick out main ideas; identifying } \\
\text { assumptions; recognizing contradictions }\end{array}$ \\
Evaluation & $\begin{array}{l}\text { Judging; comparing strengths and weaknesses; comparing against criteria; } \\
\text { assessing given criteria; looking for contradictions }\end{array}$ \\
Interpretation & $\begin{array}{l}\text { Categorizing; decoding significance; clarifying meaning; communicating in } \\
\text { different media; transferring to other subject matters }\end{array}$ \\
Inference & $\begin{array}{l}\text { Querying evidence; conjecturing alternatives; drawing conclusion } \\
\text { Explanation } \\
\text { Describing methods and results; justifying procedures; proposing and } \\
\text { defending with good reasons one's causal and conceptual explanations of } \\
\text { events or points of view }\end{array}$ \\
Self- & Self-examination and self-correction \\
regulation &
\end{tabular}

Creative thinking skill is the ability to generate and innovate novel ideas to solve old, recurring or new problems effectively. Torrence (1979) develops a framework of creative thinking which consists of four elements which are fluency, flexibility, elaboration, and originality. Fluency is being prolific in producing ideas or alternative solutions to a problem. Fluency presupposes comprehensive understanding of subjects studied. In order to achieve fluency, one has to be able to compare, convert, define, describe, explain, paraphrase, predict and summarize ideas and subject studied. Flexibility means being able to produce ideas that demonstrate multiplicity of thoughts which can generate a diversity of possibilities. It involves seeing things from multiple perspectives and using different approaches and strategies. Being flexible is being able to change, adapt, demonstrate, distinguish, apply, extrapolate, interpolate, interpret, and predict. Elaboration is a process of improving ideas by supplying more details. Adding more details and clarity to ideas will enhance the conceivability and understanding of the topics. In the elaboration process, one should be able to appraise, critique, determine, evaluate, grade, judge, measure, select, and test. Originality means being able to produce new and novelty ideas. It involves synthesis of ideas by combining them together in a different way. Being original is being able to compose, create, design, generate, modify, rearrange, reconstruct, and revise ideas. 
DEVELOPMENT

Vol. 7, No. 2, April 2018, E-ISSN: 2226-6348 @ 2018 HRMARS

Table 2: Core creative thinking skills and subskills

\begin{tabular}{ll}
\hline Core skills & Subskills \\
\hline Fluency & $\begin{array}{l}\text { compare, convert, define, describe, explain, paraphrase, predict, } \\
\text { summarise } \\
\text { change, adapt, demonstrate, distinguish, apply, extrapolate, } \\
\text { interpolate, interpret, and predict } \\
\text { appraise, critique, determine, evaluate, grade, judge, measure, select, } \\
\text { and test } \\
\text { Originality }\end{array} \quad \begin{array}{l}\text { compose, create, design, generate, modify, rearrange, reconstruct, } \\
\text { and revise ideas }\end{array}$ \\
\hline
\end{tabular}

Higher order thinking skills (HOTS) are critical and creative thinking skills. However, other scholars stated that higher order thinking is thinking logically, critically, reflectively, metacognitively, and creatively (King, Rohani \& Goodson, 1997). HOTS as informed by Bloom's Taxonomy include analysis, evaluation and creation (Anderson \& Krathwohl, 2001) which are the subskills of critical thinking. Similarly, according to Facione (2006), logical, reflective and metacognitive are also the subskills of critical thinking. Therefore, it can be concluded that HOTS is critical and creative thinking. When new information is uploaded into the mind through the senses, the mind processes the new information by correlating it with information already stored in memory. Higher order thinking takes place when new information is analysed, interpreted, evaluated, explained in relation to the existing information in the mind to come up with better understanding, elaboration, new conclusion and new ideas in form of written texts, artistic expression and solutions to solve non-routine problems (Lewis and Smith, 1993).

\section{Questioning Skills to Develop Higher Order Thinking Skills}

Thinking could not be done in a vacuum and free from context. The requirements for developing HOTS are content within and through which thinking is applied and context that is encouraging and reassuring; basic skills in thinking; and dispositions towards thinking and cognitive abilities. Students who have already fulfilled these requirements can be trained and guided to develop HOTS through relating new information to prior knowledge; and translating prior knowledge for application in new context. To develop HOTS further, students should be given multiple real-life situations that are problematic and contained uncertainties, ambiguities, confusions, dilemmas, contradictions, inconsistencies, paradoxes and challenges that compelled them to use complex analysis and HOTS to make decisions or to produce new solutions (King, Rohani \& Goodson, 1997). Teachers should make clear the outcomes of HOTS to students. Examples of such outcomes are inventions, arguments, compositions, conclusions, decisions, plans, products, recommendations, judgments, predictions, and solutions.

Teachers could stimulate HOTS by asking higher order thinking questions. Examples of higher order thinking questions are questions that are asked to analyse by inspecting ideas, identifying arguments, recognizing assumptions and spotting contradictions; to evaluate by comparing 


\section{INTERNATIONAL JOURNAL OF ACADEMIC RESEARCH IN PROGRESSIVE EDUCATION AND}

DEVELOPMENT

Vol. 7, No. 2, April 2018, E-ISSN: 2226-6348 @ 2018 HRMARS

strengths and weaknesses, assessing given criteria, and judging; to interpret by categorizing, clarifying meaning, communicating in various media, and decoding significance; to make inference by drawing conclusion, questioning evidence, and etc.; to explain by describing methods and results, justifying procedures, proposing and defending with reasons that stand critical examination; and questions that are asked to create by composing, designing, modifying, adapting, rearranging, generating, revising and reconstructing. According to Bloom Taxonomy, questions that asked for analysis, evaluation, and creation are categorized as higher order thinking questions (Anderson \& Krathwohl, 2001).

Another method of asking question for developing HOTS is asking philosophical questions. There are three types of questions: simple questions that require simple thinking; questions that are not answered yet but can be answered through empirical researches; and complex questions that require complex thinking. Questions that stimulate HOTS are complex questions that require rigorous thinking which is called philosophical questions. According to Cam (1995: 15), “... philosophical questions are essentially contentious. They do not call for correct answer. They demand further investigation and admit of different answers that may have one merit or another. They point to problem that cannot be solved by calculation, or consulting a book, or by remembering what the teacher has said. They require students to think for themselves".

Philosophical questions arise out of wonder, cognitive dissonance, and incongruity of experience (Golding, 2006). Answers to philosophical questions are insights, greater understanding and reasoned judgments. Table 4 shows the differences between various types of questions. Philosophical questions can be questions about meaning of concepts; questions about nature of realities; about theory and sources of knowledge; and questions about ethical values. Answering philosophical question provides opportunity for students to engage in critical questioning; clarifying meaning; giving and analysing justifications; probing and analysing assumptions; discovering new perspectives and alternative explanations; testing ideas; and evaluating consequences of beliefs and actions. The emphasis of a philosophical discussion is not on the end result but the process of good thinking. During philosophical discussion, students discover new depth in understanding; faults in their own thinking which enable them to make self-correction; and new perspectives. Furthermore, students are able to arrive at consensus on meanings of concepts; analyse and formulate a clear problem; build on the ideas given by others and synthesize ideas which result in creative innovation. 
Vol. 7, No. 2, April 2018, E-ISSN: 2226-6348 @ 2018 HRMARS

Table 3: Different types of questions

\begin{tabular}{|c|c|c|c|}
\hline Question Type & Problem & Resolution & Example \\
\hline $\begin{array}{l}\text { Factual } \\
\text { question }\end{array}$ & Lack of knowledge & Knowledge & What is the capital of Malaysia? \\
\hline $\begin{array}{l}\text { Clarification } \\
\text { question }\end{array}$ & Lack of clarity & Clarity & Do you mean learning or teaching? \\
\hline $\begin{array}{l}\text { Action } \\
\text { question }\end{array}$ & $\begin{array}{l}\text { Uncertainty about } \\
\text { what to do }\end{array}$ & $\begin{array}{l}\text { Make a choice of } \\
\text { what to do }\end{array}$ & $\begin{array}{l}\text { What is the cheapest way to } \\
\text { Australia? }\end{array}$ \\
\hline $\begin{array}{l}\text { Examination } \\
\text { question }\end{array}$ & $\begin{array}{l}\text { Having to prove } \\
\text { your knowledge }\end{array}$ & $\begin{array}{l}\text { Giving the right } \\
\text { answer }\end{array}$ & What is the square root of $16 ?$ \\
\hline $\begin{array}{l}\text { Philosophical } \\
\text { question }\end{array}$ & $\begin{array}{l}\text { Wonder } \\
\text { Incoherence } \\
\text { Cognitive } \\
\text { dissonance }\end{array}$ & $\begin{array}{l}\text { Greater } \\
\text { understanding } \\
\text { Insight } \\
\text { Reasoned } \\
\text { judgment }\end{array}$ & $\begin{array}{l}\text { Can we own people? } \\
\text { What is the difference between } \\
\text { change and progress? }\end{array}$ \\
\hline
\end{tabular}

Adapted from Golding (2006). What are philosophical questions? In philosophy in school:

Developing a community of inquiry, pp. 100-114. Singapore: Singapore Teachers' Union.

Similar to philosophical question is Socratic Questioning. Analysis of Plato's (1945, 1957, $1987,1993,1997,2004)$ dialogues revealed that Socrates asked questions to justify and give reasons for the meanings we assign to concepts (such as in Meno, Theaetetus, Euthyphro, and Republic); asking questions regarding the most important things in life such as how are we to live (Protagoras, Gorgias, Republic); giving justifications and reasons for truth claims, behaviour, and beliefs (most dialogues); questioning and critically examining accepted traditions (Republic); and speculating on the nature of all existence, visible and invisible, such as speculating about the soul, God, theory of forms, and so forth (Phaedo, Republic, Parmenides). Questions asked by Socrates promote the use of higher order thinking skills. By using Socratic Questioning, teachers stimulate students to clarify meanings; to uncover assumptions made by others or their own assumptions; to ask for and provide evidences, justifications and causes; to come up with implications and consequences of claims, beliefs and actions; to explain their viewpoints and perspectives; and to ask questions about questions. Paul and Elder (2006) had revised the six types of Socratic Questioning to nine types. They added questions that probe purpose; questions that probe concepts; and questions that probe inferences and interpretations to Socratic Questioning. Table 5 shows some examples of questions that can be asked by using Socratic Questioning.

Table 4: Examples of Socratic Questioning

\begin{tabular}{|c|c|}
\hline Question Types & Examples of Questions \\
\hline Questions & What do you mean by...? \\
\hline \multirow[t]{5}{*}{ Clarification } & Could you put that another way? \\
\hline & What do you think is the main issue here? \\
\hline & Could you give me an example? \\
\hline & Could you explain that further? \\
\hline & Let me see if I understand you; do you mean or...? \\
\hline
\end{tabular}




\begin{tabular}{|c|c|}
\hline & How does this relate to our discussion/problem/issue? \\
\hline $\begin{array}{l}\text { Questions that probe } \\
\text { assumptions }\end{array}$ & $\begin{array}{l}\text { What are you assuming? } \\
\text { What is Karen assuming? } \\
\text { What could we assume instead? } \\
\text { You seem to be assuming... Do I understand you correctly? } \\
\text { All of your reasoning depends on the idea that... Why have you } \\
\text { based your reasoning on...rather than...? } \\
\text { You seem to be assuming... How would you justify taking this for } \\
\text { granted? } \\
\text { Is it always the case? Why do you think the assumption holds } \\
\text { here? }\end{array}$ \\
\hline $\begin{array}{l}\text { Questions that probe } \\
\text { information, reasons, } \\
\text { evidences and causes }\end{array}$ & $\begin{array}{l}\text { How do you know? } \\
\text { What are your reasons for saying that? } \\
\text { What other information do we need to know before we can } \\
\text { address this question? } \\
\text { Is this good evidence for believing that? } \\
\text { Do you have any evidence to support your assertion? } \\
\text { How does that information apply to this case? } \\
\text { Is there reason to doubt that evidence? } \\
\text { What do you think is the cause? }\end{array}$ \\
\hline $\begin{array}{l}\text { Questions } \\
\text { viewpoints } \\
\text { perspectives }\end{array}$ & $\begin{array}{l}\text { You seem to be approaching this issue from perspective. Why } \\
\text { have you chosen this perspective rather than that perspective? } \\
\text { How would other groups or types of people respond? Why? } \\
\text { What would influence them? } \\
\text { How could you answer the objection that would make? } \\
\text { Can/did anyone see this another way? } \\
\text { What would someone who disagrees say? } \\
\text { What is an alternative? } \\
\text { How are Karim's and Rozana's ideas alike? Different? }\end{array}$ \\
\hline $\begin{array}{l}\text { Questions that probe } \\
\text { implications } \\
\text { consequences }\end{array}$ & $\begin{array}{l}\text { What are you implying by that? } \\
\text { When you say..., are you implying...? } \\
\text { But if that happened, what else would also happen as a result? } \\
\text { Why? What effect would that have? } \\
\text { Would that necessarily happen or only probably happen? } \\
\text { What is an alternative? } \\
\text { If this and this are the case, then what else must be true? }\end{array}$ \\
\hline $\begin{array}{l}\text { Questions } \\
\text { questions }\end{array}$ & $\begin{array}{l}\text { How could someone settle this question? } \\
\text { Can we break this question down at all? } \\
\text { Is the question clear? Do we understand it? } \\
\text { What does this question assume? }\end{array}$ \\
\hline
\end{tabular}


Why is this question important?

Does this question ask us to evaluate something?

To answer this question, what other questions would we have to answer first?

Adapted from Paul and Elder (2006). The thinker's guide to the art of Socratic Questioning. Tomales, California: Foundation for Critical Thinking.

Teacher also could assist students to distinguish between the levels of questions to promote HOTS via Question Quadrant. This method was developed by Philip Cam (2006) who introduced this thinking tool in his book titled "20 Thinking Tools: Collaborative Inquiry for the Classroom". Questions grouped in quadrant one and quadrant two are factual and speculative questions respectively. These questions require simple thinking to deliberate on the answers; and the answers can be found in the texts or materials used. Quadrant three questions are questions that require research. The answers to these questions can be found in books, reports, knowledge held by experts; and can be answered through research. Quadrant four questions are philosophical questions which require the use of HOTS in order to answer the questions. Answers to these questions are sound arguments, justified beliefs, reasoned judgment, insights and greater understanding. Questions that are grouped under quadrant three and four are questions that promote the use of higher order thinking skills.

\section{Research Method}

This research employed qualitative research method of case study which is "as an empirical inquiry that investigates a contemporary phenomenon within its real-life context; when the boundaries between phenomenon and context are not clearly evident; and in which multiple sources of evidence are used" (Yin, 2009: 18). Specifically, case study used in the study was exploratory. Exploratory case study was employed to obtain an insight of a problematic situation in the actual setting to examine the actual behaviour with minimum interference that may obstruct the reality. This exploratory case study attempted to gain wider perspective and deeper understanding of the problem investigated to assist understanding of this problem in the whole population (Stake, 1995). Specifically, the researchers endeavoured to describe teachers' specific knowledge and practices in implementing teaching for higher order thinking skills to gain a perspective of the problem of teaching for HOTS at large. However, the findings of this study only described the teachers of that school and not to be generalized to other primary school teachers in Malaysia. It used HOTS as defined by Facione (2006), Torrence (1979) and Bloom's Taxonomy (Anderson and Krathwohl, 2001) to guide researchers in data collection to assess teachers' knowledge and skills on HOTS. To gauge teachers' skills in teaching for HOTS, this study evaluated teachers' knowledge and skills in asking questions based on Socratic Questioning, Question Quadrant and Bloom's Taxonomy. Teachers were asked to indicate the type of questions asked during teaching and learning processes using a checklist with Likert-type scale of 1 to 5 . The scale of 1 means very rarely, 2 rarely, 3 sometimes, 4 often and 5 always. Observations while teachers teaching were made using the same checklist to validate the self-reporting checklist. 
Vol. 7, No. 2, April 2018, E-ISSN: 2226-6348 @ 2018 HRMARS

The participants for this research were nine teachers who taught at a primary school in Kuala Terengganu, Malaysia, which is considered as an urban school. All teachers have had experience of teaching for more than 15 years. Three of the teachers taught Malay Language; three taught Science; and the last three teachers taught Mathematics. This study attempted to gather information on teachers' knowledge on HOTS and their knowledge and skills on teaching for HOTS in order to assess their understanding on HOTS and their knowledge and skills on using questioning methods to develop HOTS in students. Therefore, the most suitable method of data collection was in-depth interviews, teachers' self-reports and observation of the teachers while they were teaching. Self-report checklist with items representing questioning methods by Bloom's Taxonomy, Socratic Questioning and Question Quadrant were given to teachers to indicate their practices in classrooms and the same checklist was used during observations to validate the data collected using teachers' self-reports. Interview questions were asked to determine the level of knowledge the teachers have on HOTS and their skills on teaching for HOTS. The interviews were recorded and transcribed verbatim. Besides, the researchers also video-taped the learning sessions to corroborate the checklist done during observations in the classroom. The collected data was analysed based on the themes put forward by Bloom's Taxonomy, Facione (2006), and Torrence (1979) to find out about teachers' knowledge; and Bloom's Taxonomy, Socratic Questioning, and Question Quadrant to find out teachers' knowledge and skills in questioning to stimulate HOTS.

\section{Research Findings}

Data collected through interviews and observations were analysed to assess teachers' understanding of the concept of thinking and thinking process and their knowledge of HOTS; and to evaluate their questioning skills. The themes that emerged from the data were compared to the concept of thinking, thinking process and HOTS explained in previous sections of this paper. The following sections present the findings of this study.

\section{Teacher Knowledge on HOTS}

Analysis of data collected from interviews revealed teachers' knowledge on HOTS. Teachers did not explain or demonstrate their understanding of the concept of thinking and how thinking process occurred in human mind. Instead they listed the different types of thinking skills. Teachers also could not give satisfactory explanation of the concept of HOTS. They merely listed thinking skills of HOTS but they could not elaborate those skills explicitly and clearly. GB2T5 and GS2T5 listed nothing more than "...creative thinking skills and critical..." as HOTS; while GB3T6 expanded the list to include "...creative thinking skills, critical thinking, reasoning, decision making..." as HOTS. Similarly, GS1T4 listed more skills such "...critical thinking skills, creativity, logical thinking skills, information, skills to compare and differentiate, characterize, welding skills..." as HOTS. While these responses were correct, however further probing illustrated that teachers could not elucidate what they understood by critical and creative thinking and how critical thinking differs from creative thinking. They failed to demonstrate the ability to analyze and interpret the subskills of critical and creative thinking and communicate their understanding 


\section{INTERNATIONAL JOURNAL OF ACADEMIC RESEARCH IN PROGRESSIVE EDUCATION AND}

DEVELOPMENT

Vol. 7, No. 2, April 2018, E-ISSN: 2226-6348 @ 2018 HRMARS

orally using their own language. The manifestation of understanding is the ability to explain until others can understand and translate the understanding into action.

Further, the teachers were asked to explain what they understood by HOTS. Instead of explicating the core and subskills of critical and creative thinking, all teachers listed what they thought the core and subskills of HOTS were. The lists produced by teachers were evaluated based on the core and subskills of critical thinking explained by Facione (2006) and creative thinking explained by Torrence (1979). The findings revealed the core skills of HOTS, according to the teachers were analysis, evaluation and creating. This is because all teachers were exposed to Bloom's Taxonomy during pre-servive and in-service training. Analysis and evaluation are two out of six core skills of critical thinking (Facione 2006). The other four core skills are interpretation, inference, explanation, and self-regulation. Creating is not one of the core skills of creative thinking expounded by Torrence, rather creating encompasses all four core skills of creative thinking.

However, knowing analysis, evaluation and creating as HOTS did not mean that the teachers understood these concepts clearly. Teacher GB1T4 listed problem solving as the subskill of analysis. This is confusing because problem solving is the process of finding solution which involves multiple stages of process; and analysis is the beginning of the process after facts and information were collected. In other words, analysis is one of the subskills of problem solving. This teacher also listed making decision as a subskill of evaluation. Evaluation is a process required in order to choose the most efficient and effective solution among the available solutions. Making decision is choosing among alternatives. The skill needed to make decision is evaluation. It is absurd to say that the skill required in a process of evaluation is making decision. This teacher, however, seemed to understand the skill of creating very well. He listed making analogies, combining ideas to create new things, and making visualization as subskills of creating. He also thought that self-reflection was a subskill of creating but Facione (2006) explained selfreflection as a core skill of critical thinking.

Teacher GB2T5 understood analysis as breaking down whole into parts and problem solving. Similar with GB1T4, this teacher also listed decision making as a subskill of evaluation. In addition, he also listed clarifying and arguing as the subskills of evaluation. According to Facione (2006), clarifying is a subskill of a core critical thinking skills of interpretation; and arguing is a subskill of analysis. Amazingly, this teacher explained that the subskill of creating involved composing poems, making sentences, communicating and dialogue, visualizing and writing reflections. This is consistent with the subskills of creative thinking expounded by Torrences (1979).

The third Malay Language teacher, GB3T6 correctly explained that analysis is the process of dividing whole into parts and making connections between ideas. However, she demonstrated superficial understanding of analysis when she listed choosing and problem solving as part of doing analysis. This teacher aslo enumerated decision making as the skill needed in evaluation process and the core skill of explanation as a process necessary in evaluation. All the Malay Language teachers seemed to be confused on analysis and evaluation but surprisingly, they demonstrated good understanding on the skill of creating. For this teacher, the skill of creating 


\section{INTERNATIONAL JOURNAL OF ACADEMIC RESEARCH IN PROGRESSIVE EDUCATION AND}

DEVELOPMENT

Vol. 7, No. 2, April 2018, E-ISSN: 2226-6348 @ 2018 HRMARS

involved making analogies, naming themes, composing poems, generating new ideas, and devising a scheduled plan.

As for Mathematics teachers, all three of them mentioned problem solving and choosing appropriate tools to solve problem as subskills of analysis. Only teacher GM3T6 added identifying relationship between concepts as part of doing analysis. Similarly, these teachers also counted skills of decision making, explanation and interpretation as necessary tools for evaluation. Only teacher GM3T6 could explain skill of creating well. According to him, creativity can be promoted through looking at something from multiple perspectives, writing self-reflections, sharing concepts and ideas, developing different ways of solving problems, and visualizing.

Two Science teachers held a similar view that problem solving is an important subskill for analysis. However, they correctly explained that analysis is breaking down whole into parts to identify connections between components, ideas and concepts. Only teacher GS2T5 did not mention solving problem as a subskill of analysis. Like the other teachers, all Science teachers except teacher GS2T5 include decision making as a skill needed to evaluate. They also seemed to be confused between the evaluation skill and expalanation skill. As for the skill of creating, all teachers gave good explanation when they mentioned testing, making hypothesis, combining many ideas and concepts, building new knowledge, visualizing, designing own activities, integrating ideas and concpets, and making analogies as parts of creating.

In conclusion, analysis of the data indicated that teachers' understanding of the concept of thinking, thinking process, and HOTS were very minimal. Even though they rightly mentioned HOTS as critical and creative thinking but they failed to explain the differences between the core and subskills of critical and creative thinking. The teachers' only listed analysis, evaluation and creating as core skills of HOTS but failed to mention other core critical thinking skills such as interpretation, translation, inference and self-regulation; and core creative thinking skills of fluency, originality, elaboration, and flexibility. Sadly, all teachers seemed so confused on the concept of problem solving and decision making. These findings were consistent with the findings discovered by Nooriza Kassim and Effandi Zakaria (2015) and Mohd Nazri et al. (2017). Teachers' knowledge on HOTS was limited to Bloom's Taxonomy because they were trained to write lessons' objectives and to evaluate students' performance at the end of lessons using Bloom's Taxonomy. Moreover, they were given the handbook of standard content which contained detailed explanations and suggested activities of how to use Bloom's Taxonomy to teach for thinking.

\section{Skills of Asking Questions to Teach for HOTS}

Researchers distributed a checklist for each teacher to indicate the types of questions he or she normally asked during teaching and learning sessions. The teachers were also observed four times to validate the data collected via self-reporting checklist. Findings from Likert-type checklist are presented in Table 5. Question Quadrant 1 and 2 are lower order thinking skills (LOTS) questions; and Question Quadrant 3 and 4 are HOTS questions. The findings revealed that all nine teachers always asked LOTS questions. Five teachers often asked HOTS questions and four teachers sometimes asked HOTS questions. Teacher GB1T4 very rarely asked question from 


\section{INTERNATIONAL JOURNAL OF ACADEMIC RESEARCH IN PROGRESSIVE EDUCATION AND}

DEVELOPMENT

Vol. 7, No. 2, April 2018, E-ISSN: 2226-6348 @ 2018 HRMARS

quadrant four and rarely asked questions from quadrant 3. For the method of asking using Socratic Questioning, only two science teachers often and always asked this type of questions. All Socratic Questions are questions that promote HOTS. Majority of teachers did not use Socratic Questioning because they were not familiar of or have no knowledge about this method of asking question.

Majority of teachers often and always asked questions of application and analysis using Bloom's Taxonomy. From Table 5, number 1, 2, 3, and 4 represent application, analysis, evaluation and create respectively from Bloom's Taxonomy. The table shows that all teachers often and always asked questions of application and analysis. Questions that asked students to analyse, evaluate and create are HOTS questions. Only four teachers often asked questions of evaluation and five teachers sometimes asked evaluation questions. Surprisingly four teachers rarely asked questions to create and five teachers sometimes asked questions to create. This means that most of the times teachers were not asking questions to develop creativity among students. This is because they spent most of the times to ask factual or recalling questions. The highest level of questions asked by all teachers were analysis questions. It is surprising because all teachers were given a handbook of standard content that used Bloom's Taxonomy as the method to write lessons' objectives and method to ask questions to evaluate students' performances at the end of lessons. These findings revealed that majority of teachers asked questions that only require LOTS compared to HOTS as shown by Question Quadrant in Table 5. Less than $50 \%$ of the teachers often and always asked questions to promote HOTS using Bloom's Taxonomy. The data also revealed that science teachers often and always asked questions to develop HOTS. Whereas Malay Language teachers always asked LOTS questions.

Table 5: Frequencies of question types asked during teaching and learning sessions

\begin{tabular}{|c|c|c|c|c|c|c|c|c|c|c|}
\hline Question & & GB1T & GB2T & GB3T & GM1T & GM2T & GM3T & GS1T & GS2T & GS3T \\
\hline \multirow[t]{2}{*}{ Types } & & 4 & 5 & 6 & 4 & 5 & 6 & 4 & 5 & 6 \\
\hline & 1 & 5 & 4 & 5 & 5 & 4 & 5 & 5 & 5 & 5 \\
\hline Question & 2 & 4 & 4 & 4 & 5 & 4 & 5 & 4 & 4 & 5 \\
\hline \multirow[t]{3}{*}{ Quadrant } & 3 & 2 & 3 & 3 & 4 & 4 & 4 & 4 & 3 & 4 \\
\hline & 4 & 1 & 2 & 2 & 2 & 2 & 3 & 4 & 2 & 4 \\
\hline & 1 & 2 & 2 & 3 & 3 & 2 & 3 & 4 & 2 & 5 \\
\hline Socratic & 2 & 3 & 2 & 3 & 3 & 3 & 3 & 4 & 3 & 4 \\
\hline Questionin & 3 & 3 & 3 & 2 & 3 & 3 & 3 & 3 & 3 & 5 \\
\hline \multirow[t]{4}{*}{ g } & 4 & 2 & 2 & 2 & 1 & 2 & 2 & 3 & 2 & 4 \\
\hline & 5 & 3 & 3 & 3 & 3 & 3 & 3 & 3 & 3 & 4 \\
\hline & 6 & 3 & 3 & 3 & 3 & 3 & 2 & 3 & 3 & 3 \\
\hline & 1 & 4 & 4 & 5 & 5 & 4 & 5 & 4 & 4 & 5 \\
\hline Bloom's & 2 & 4 & 4 & 4 & 5 & 4 & 5 & 4 & 4 & 5 \\
\hline \multirow[t]{2}{*}{ Taxonomy } & 3 & 3 & 3 & 4 & 4 & 3 & 3 & 4 & 3 & 4 \\
\hline & 4 & 2 & 2 & 3 & 3 & 2 & 3 & 3 & 2 & 3 \\
\hline
\end{tabular}


DEVELOPMENT

Vol. 7, No. 2, April 2018, E-ISSN: 2226-6348 @ 2018 HRMARS

The interview data revealed that teachers could vaguely explain questioning techniques other than Bloom Question Type. They did not answer the questions about their knowledge on these techniques of asking questions but they used body language to indicate that they had no idea or never heard about these questioning techniques. GB1T4 answered our questions on Socratic Questioning by frowning and shrugging; GB3T6 by shaking his head and raising both shoulders; GM1T4 by shaking his head and frowning; GS2T5 by rubbing his chin thoughtfully with a puzzled gaze. In addition, they further demonstrated their confusion by stating "...Socrates is questioning techniques using open-ended questions..." (GM2T5 and GS3T6); "...Open-ended questions..." (GS1T4); "...Questioning that begins with simple questions, then more and more difficult..." (GB2T5). These findings showed teachers knew HOTS as explained by Bloom's Taxonomy but were not aware of other available techniques. This probably because the teachers were supplied by a hand book on standard content which contained Bloom's Taxonomy. This also may indicate that teachers were not into equipping themselves with skills other than what they were being instructed to do. Life-long learning probably was not the culture of these teachers. It was no surprise that teachers found it hard to innovate new ideas because how can they innovate when they had only very basic understanding of HOTS.

\section{Discussion and Conclusion}

This study has raised a pertinent issue of the level of knowledge primary school teachers have on the concept of thinking and HOTS and teaching for HOTS through questioning methods. It has presented compelling evidences that teachers could barely explain the meaning of thinking and its processes. What is more to explicate the meaning and skills of higher order thinking. In order for teachers to train students to use higher order thinking skills, teachers themselves should master the skills first because teachers cannot give what they do not have. The findings support Rosma, Ong, Shakinaz and Wong's (2013) and Abdul Halim and Siti Muhibbah's (2105) conclusion that teachers seriously needed to improve their knowledge on HOTS and how to teach for HOTS. The present study also discovers that teachers had very basic knowledge on questioning methods and they were not skillful in asking higher order thinking questions. This means that teachers were not teaching for thinking. This finding is consistent with the outcomes of studies conducted by Nooriza and Effandi (2015) and Mohd Nazri et al. (2017).

Majority of teachers asked lower order thinking questions to test students' memorization of facts and comprehension. Furthermore, the study finds that teachers only knew and frequently asked questions based on Bloom's Taxonomy. This is because teachers were trained to use Bloom's Taxonomy when preparing the objectives of their lessons; and examples of Bloom's questioning techniques are given in the document of Curriculum Standard Content provided by Ministry of Education. This also implied that the culture of continuing education and improving professional skills was not practised well in this primary school. This study suggests that incentive, be it, intrinsic or extrinsic should be given to encourage teachers to be always up to date with new skills. This is important since they are going to educate future generations who are knowledgeable and well equipped with skills including HOTS so that they could participate in the global arena. 
Vol. 7, No. 2, April 2018, E-ISSN: 2226-6348 @ 2018 HRMARS

Precisely, this study forwards some of the reasons for the discouraging achievement of Malaysian students on thinking and reasoning as reported by the Ministry of Education, which is teachers' lack of knowledge in HOTS and their incompetency in questioning for higher order thinking skills. Findings of this study is significant to inform policy makers in education to be aware of the existing problems that require effective actions. However, the findings of this study could not be generalized to the whole population. More studies should be conducted to make conclusion on the status of teachers' knowledge and skills in teaching for higher order thinking. This study also keeps the conversations on the problems within the education and schooling system going so that necessary actions could be taken. When conversations of certain issues died out, planning and actions for improvement are far from the authority's agenda. This study also added to the much-needed evidences to support those who propose for improvement in our education system.

\section{References}

Abdul Halim, T. \& Siti Muhibah, H. N. (2015). Prinsip Pembelajaran Aktif dalam Pengajaran dan Pembelajaran Pendidikan Islam. Jurnal Pendidikan Fakulti Pendidikan, 3(2), 28-42.

Abdul Halim, A., Baharuddin, A., Muhammad Sukri, S., Boon, Y. \& Saidatul Akmal, A. A. (2015). Pelaksanaan Kemahiran Berfikir Aras Tinggi (KBAT): Isu dan Cabaran Dalam Aspek Kurikulum, Pedagogi dan Pentaksiran. Seminar Kebangsaan Majlis Dekan-dekan Pendidikan Universiti Awam.

Anderson, L. W., \& Krathwohl, D. R. (2001). A taxonomy for learning, teaching and assessing: A revision of Bloom's Taxonomy of educational objectives. New York: Longman.

Cam, P. (1995). Thinking together: Philosophical inquiry for the classroom. Sydney: Australia: Hale \& Iremonger Pty. Ltd.

Facione, P.A. (2006). Critical Thinking: What It Is and Why It Counts-2006 Update. Retrieved July 28, 2006, from http://www.insightassessment.com/pdf files/what\&why2006.pdf

Al-Ghazali. (2007). Wonders of the heart. (W. J. Skellie, Trans.). Kuala Lumpur: Islamic Book Trust. Golding, C. (2006). What are philosophical questions? Paper presented at the Conference of Philosophy in Schools: Developing a Community of Inquiry. Organized by Singapore Teachers' Union. April 17-18.

King, F.J., Rohani, F., \& Goodson, L. (1997). Statewide assessment of listening and verbal communication skills, information literacy skills, and problem-solving skills. Tallahassee: Florida State University.

Lewis, A., \& Smith, D. (1993). Defining higher order thinking. Theory into Practice, 32(3), 131-137.

Ministry of Education Malaysia. (2013). Malaysian education blueprint 2013-2025. Putrajaya: MOE.

Mohd Azhar A. H., Mohd. Koharuddin, B., \& Muhamed Fauzi, O. (2006). Rekacipta dan inovasi dalam perspektif kreativiti. Skudai: Penerbit UTM.

Mohd Nazri, H., Ramlee, M., Nik Azimah, N. Y., \& Rosnidar, M. (2017). Pembangunan modul KBAT dalam mata pelajaran sains sekolah rendah: Analisis keperluan guru. Sains Humanika, 9(15), 119-125. 
INTERNATIONAL JOURNAL OF ACADEMIC RESEARCH IN PROGRESSIVE EDUCATION AND

DEVELOPMENT

Vol. 7, No. 2, April 2018, E-ISSN: 2226-6348 @ 2018 HRMARS

Najeemah, M. Y. (2007). Penggabung Jalinan dan Penyerapan dalam Pengajaran aan Pembelajaran Pensyarah untuk Melahirkan Modal Insan Di IPTA. Persidangan Pengajaran dan Pembelajaran Di Peringkat Pengajian Tinggi 2007. Kuala Lumpur: Universiti Putra Malaysia. pp. 33-40.

Nooriza, K. \& Effandi, Z. (2015). Integrasi kemahiran berfikir aras tinggi dalam pengejaran dan pembelajaran matematik: Analisa keperluan guru. Jurnal Pendidikan Matematik, 3(1), 112.

Nor Hasmaliza, H. \& Zamri, M. (2016). Persepsi guru Bahasa Melayu sekolah menengah terhadap KBAT. Jurnal Pendidikan Bahasa Melayu - JPBM (Malay Language Education Journal MyLEJ), 6(2), 78-90.

Paul, R. \& Elder, L. (2006). The thinker's guide to the art of Socratic Questioning. Tomales, California: Foundation for Critical Thinking.

Plato. (1945). The republic of Plato. (F. M. Conford, Trans.). London: Oxford University Press.

Plato. (1957). Protagoras and Meno. (W.K.C. Guthrie, Trans.) London: Penguin Classics.

Plato. (1987). Theatetus. (R.H. Waterfield, Trans.). London: Penguin Classics.

Plato. (1993). The last days of Socrates: Euthyphro; the Apology; Crito; Phaedo. (H. Tarrant \& H. Tredennick, Trans.). London: Penguin Classics.

Plato. (1997). Parmenides. (R.E. Allen, Trans.). New Haven: Yale University Press.

Plato. (2004). Gorgias. (C. Emlyn-Jones \& W. Hamilton, Trans.). London: Penguin Classics.

Pohl, M. (2000). Learning to think, thinking to learn: Models and strategies to develop a classroom culture of thinking. Cheltenham, Victoria: Hawker Brownlow.

Rosma, O., Ong, E. T., Shakinaz, D., \& Wong, K. T. (2012). Tahap Kemahiran Berfikir dalam Kalangan Guru Sekolah Rendah. Jurnal Pendidikan Bitara UPSI, 5(1), 1-11.

Rosnani, H. \& Suhailah, H. (2003). The teaching of thinking in Malaysia. (1 $1^{\text {st }}$ Ed.) Kuala Lumpur: Research Management Centre, International Islamic University Malaysia.

Siti Marlina, S. (2013). Kemahiran berfikir aras tinggi (KBAT) pelajar tingkatan lima dalam penyelesaian masalah Matematik. Master's thesis, Universiti Teknologi Malaysia, Faculty of Education.

Stake, R. E. (1995). The art of case study research. Thousand Oaks, CA: Sage Publications.

Torrence, P. (1979). The search for satori and creativity. Buffalo, New York: Creative Education Foundation.

Yahya, O. (2016). Perlaksanaan kemahiran berfikir dalam pengajaran Bahasa melayu dari perspektif guru (2016). Jurnal Bahasa, 136-159. http://jurnalbahasa.dbp.my/wordpress/wp-content/uploads/2016/04/6-PelaksanaanKemahiran-Berfikir-dalam-Pengajaran-Bahasa-Melayu.pdf

Yee, M. H., Jailani, M. Y., Razali, H., Mimi Mohaffyza, M., Widad, O., \& Tee, T. K. (2013). Penilaian Kualiti Manual Pembelajaran Kendiri Pengintegrasian Gaya Pembelajaran Kolb Dan Kemahiran Berfikir Aras Tinggi Marzano. Proceeding of the International Conference on Social Science Research (4-5 June), 1357-1368.

Yin, R.K. (2009). Case study research. Design and methods. ( $4^{\text {th }}$ ed.). Thousand Oaks, California: Sage Publications. 
INTERNATIONAL JOURNAL OF ACADEMIC RESEARCH IN PROGRESSIVE EDUCATION AND DEVELOPMENT

Vol. 7, No. 2, April 2018, E-ISSN: 2226-6348 @ 2018 HRMARS

Zulkarami, M. J. (2011). Pelaksanaan Kemahiran Berfikir Secara Kreatif dalam Pengajaran di Institut Perguruan Tawau, Sabah. Master's Thesis. Universiti Teknologi Malaysia. 